\title{
Patterns of Chondroitin Sulfate Immunoreactivity in the Developing Tectum Reflect Regional Differences in Glycosaminoglycan Biosynthesis
}

\author{
Diane Hoffman-Kim, ${ }^{1}$ Arthur D. Lander, ${ }^{2}$ and Sonal Jhaveri ${ }^{1}$ \\ ${ }^{1}$ Department of Brain and Cognitive Sciences, Massachusetts Institute of Technology, Cambridge, Massachusetts 02139, \\ and ${ }^{2}$ Department of Developmental and Cell Biology and Developmental Biology Center, University of California, Irvine, \\ Irvine, California 92697
}

The glycosaminoglycan chondroitin sulfate (CS) is expressed in many parts of the developing brain, both in regions where axons preferentially grow and in areas that axons distinctly avoid. Some in vitro studies suggest that CS and proteoglycans (PGs) that carry CS enhance axon growth, whereas others suggest that CS and CSPGs inhibit it. In the developing hamster, there is evidence that midbrain raphe cells act as a barrier to prevent growth of optic axons across the tectal midline. Here we show that in the newborn hamster, CS immunoreactivity is substantially higher in midline than in lateral tectum, raising the possibility that CSPGs play a role in the unilateral containment of optic axons. However, analysis of tectal PGs by anion exchange chromatography and denaturing gel electrophoresis failed to detect substantial differences between midline and lateral tectum in either the types or relative amounts of CSPG and heparan sulfate PG protein cores. In contrast, metabolic

Proteoglycans (PGs), molecules that consist of a protein core with one or more covalently attached glycosaminoglycan (GAG) chains, are thought to play roles in a wide range of biological processes, including mechanical and structural support, cell adhesion, motility, and differentiation (for review, see Kjellén and Lindahl, 1991). Within the nervous system, PGs have been proposed to participate in numerous developmental events, including cell migration (Streit et al., 1993), axon guidance (Snow et al., 1990a; Bicknese et al., 1994; Dou and Levine, 1994), neural plasticity (Zaremba et al., 1989; Kalb and Hockfield, 1990), and neuronal survival (Huxlin et al., 1993, 1995a,b; Nichol et al., 1994, 1995; Okamoto et al., 1994; Junghans et al., 1995). Certain PGs are upregulated after injury (Levine, 1994) and in regeneration (Pindzola et al., 1993; Braunewell et al., 1995).

PGs of one class, the chondroitin sulfate proteoglycans (CSPGs), are found to be prominently expressed both in regions of the developing nervous system where axon pathways form

\footnotetext{
Received June 30, 1997; revised May 13, 1998; accepted May 18, 1998.

This work was supported by National Institutes of Health Grants EY05504 (S.J.), NS26862 (A.D.L.), EY06565 (D. H.-K.), and EY02621 (Massachusetts Institute of Technology Vision Core Grant). We are grateful to Mary Herndon, Jon Ivins, and Chris Stipp for helpful discussions, to Angela Sower, Anna Borkowska, Jason Glanz, and Tat Fong $\mathrm{Ng}$ for technical assistance, and to Chrysty Remillard for assistance with photography.

Correspondence should be addressed to Dr. Sonal Jhaveri, Department of Brain and Cognitive Sciences, E25-642a, Massachusetts Institute of Technology, Cambridge, MA 02139.

Dr. Hoffman-Kim's present address: Department of Molecular and Cellular Biology, Harvard University, Cambridge, MA 02138.

Copyright (C) 1998 Society for Neuroscience $\quad 0270-6474 / 98 / 185881-10 \$ 05.00 / 0$
}

labeling of tectal slices in vitro documented that incorporation of ${ }^{35}$ S-sulfate into macromolecules is significantly increased at the tectal midline, in a pattern resembling chondroitin sulfate immunoreactivity. This difference was evident whether slices were labeled for $1 \mathrm{hr}$ or overnight and was not paralleled by a difference in overall protein synthesis, suggesting that the rate of synthesis of sulfated macromolecules is specifically elevated in midline tectum. We propose that the concentration of CS at the midline of the developing tectum is a reflection of a higher rate of synthesis or sulfation of glycosaminoglycans by midline cells, rather than a higher level of production of any particular CSPG. These results suggest that the distribution of some axon guidance signals in development may be controlled by differential regulation of glycosaminoglycan biosynthetic enzymes.

Key words: axon guidance; chondroitin sulfate; visual system; tectal midline; glia; rodent

(Flaccus et al., 1991; Sheppard et al., 1991; Bicknese et al., 1994; Ring et al., 1995) and in areas that axons avoid (Snow et al., 1990a; Oakley and Tosney, 1991; Perris et al., 1991; Brittis et al., 1992; Pindzola et al., 1993; Oakley et al., 1994; Landolt et al., 1995). These expression patterns have generated interest in the potential functions of CSPGs in axon guidance. While some in vitro studies suggest that CSPGs, as well as CS itself, enhance neurite elongation (Lafont et al., 1992, 1994; Faissner et al., 1994; Fernaud-Espinosa et al., 1994), other experiments indicate that CSPGs and CS inhibit neurite outgrowth (Snow et al., 1990b, 1991; Fichard et al., 1991; Oohira et al., 1991; Brittis et al., 1992; Snow and Letourneau, 1992; Brittis and Silver, 1994; Dou and Levine, 1994; Maeda and Noda, 1996). Some of the reported effects of CSPGs are blocked when CS chains are removed (leaving behind the core protein), whereas others are not (Snow et al., 1990b; Iijima et al., 1991; Oohira et al., 1991; Lafont et al., 1992, 1994; Katoh-Semba and Oohira, 1993; Faissner et al., 1994; Maeda and Noda, 1996).

A role for CSPGs in axon guidance has been strongly asserted for the developing vertebrate visual system. Retinal ganglion cell axons steer away from CS-containing substrata in vitro (Snow et al., 1991; Snow and Letourneau, 1992), and their behavior after enzymatic removal of CS from retinal organ cultures suggests that CSPGs play a role in deflecting ganglion cell axons from the retinal periphery and directing them toward the optic disk (Brittis et al., 1992). Interestingly, retinal axons also appear to be repelled by an inhibitory cue found at the distal end of their traverse, in the midline of the superior colliculus, or optic tectum. Developing 
retinal axons normally do not cross the tectal midline in vivo (Schneider, 1973, Wu et al., 1995; Jhaveri et al., 1996) but will cross abnormally into the opposite tectum when specialized midline raphe cells are experimentally damaged (So and Schneider, 1978; Poston et al., 1988; Wu, 1991; Wu et al., 1995). In vitro, retinal axons prefer to extend long processes on substrates of glia harvested from the lateral tectum rather than from midline tectum (Sower et al., 1996).

Here we explore the possibility that CSPGs at the tectal midline may play a role in mediating the inhibitory effects of this structure on growing optic axons. We show by immunostaining that CS is concentrated at the tectal midline and appears there around the time that retinal axons grow into the region. Furthermore, we provide evidence that this concentration of CS is likely to be attributable to increased synthesis of glycosaminoglycans and not to specific CSPG core proteins. This apparent distinction in regional metabolism has potential implications for the role of specific glycosylation in the formation of axonal boundaries throughout the nervous system.

Some of these data have been reported previously in abstract form or in review chapters (Jhaveri, 1993a,b; Hoffman et al., 1994; Hoffman-Kim et al., 1995, 1996; Jhaveri and HoffmanKim, 1996).

\section{MATERIALS AND METHODS}

Chemical reagents were purchased from Sigma (St. Louis, MO), unless noted otherwise.

Immunohistochemistry. Postnatal day (P) 0 hamster pups were killed by intraperitoneal injection of sodium pentobarbitol $(>50 \mathrm{mg} / \mathrm{kg})$ and perfused transcardially with $5 \mathrm{ml}$ of $0.1 \mathrm{M}$ phosphate, $\mathrm{pH} 7.4$, plus $0.9 \% \mathrm{NaCl}$ (PBS), followed by $5 \mathrm{ml}$ of $4 \%$ paraformaldehyde in PBS. Heads were removed, post-fixed at $4^{\circ} \mathrm{C}$ by immersion in fixative for $1 \mathrm{hr}$, and stored in PBS at $4^{\circ} \mathrm{C}$. Brains were cryoprotected, and $50 \mu \mathrm{m}$ coronal sections were cut frozen on a sliding microtome. Nonspecific staining was blocked by incubating free-floating sections for $1 \mathrm{hr}$ at room temperature in PBS containing $5 \%$ normal goat serum plus $0.1 \%$ Triton $\mathrm{X}-100$. Sections were next incubated at $4{ }^{\circ} \mathrm{C}$ either for $2 \mathrm{~d}$ in CS-56 [a monoclonal antibody raised against chondroitin sulfate (Sigma)] diluted 1:100 in buffer, or for $1 \mathrm{~d}$ in a monoclonal antibody against vimentin (Boehringer Mannheim, Indianapolis, IN) diluted 1:50 in buffer. They were rinsed in PBS, reacted with a fluorescently tagged goat anti-mouse $\operatorname{IgG}$ (1:200 dilution in buffer), rinsed, mounted on subbed slides, and coverslipped with Fluoromount (Fisher, Pittsburgh, PA). Sections were examined on a Nikon Optiphot microscope equipped with epifluorescence optics and an appropriate filter cube, and photographed. For analysis, sections immunostained with the CS-56 antibody were examined on a Nikon Eclipse E800 microscope, and images were captured using an Optronics DEI-470T CCD video camera system with two-stage thermoelectric Peltier cooling. Relative levels of fluorescence in different regions were analyzed using the Adobe Photoshop software program. Specifically, pixel values in $50 \times$ $50 \mu \mathrm{m}$ square regions in dorsal, middle, and ventral areas of midline and lateral tectum were measured using the Histogram function. One square was measured in each midline region, and five squares were averaged in each lateral tectum region.

Tissue preparation. For PG isolation, $\mathrm{P} 0$ hamsters were anesthetized by hypothermia, and the brains were removed into ice-cold Gey's balanced salt solution (Life Technologies, Grand Island, NY) containing $6.5 \mathrm{gm} / 1$ glucose. The midbrain tectum was dissected out, stripped of meninges, and separated into midline $(\sim 500 \mu \mathrm{m}$ in width) and lateral regions (two pieces, each $\sim 900 \mu \mathrm{m}$ in width). For metabolic labeling experiments, the midbrain was stripped of meninges and cut with a McIlwain tissue chopper into $300 \mu \mathrm{m}$ coronal slices. Slices through the superior colliculus were positioned on tissue culture inserts (Millicell CM, $0.4 \mu \mathrm{m}$ pore size, $30 \mathrm{~mm}$ diameter; Millipore, Bedford, MA), placed in six-well tissue culture plates, and incubated in $1 \mathrm{ml}$ of medium (see "Metabolic labeling of tectal slices," below). This keeps a film of medium between the upper surface of the slice and the air, and allows the lower surface to contact the culture medium through the filter.

Subcellular fractionation. Subcellular fractionation, isolation, and radioiodination of PGs were performed at $4^{\circ} \mathrm{C}$ as described by Herndon and Lander (1990), with tissue from midline and lateral tectum processed in parallel. Tissues were rinsed in PBS and resuspended in at least 9 vol of buffer A (0.3 M sucrose, 4 mM HEPES, $\mathrm{pH} 7.5$, with protease inhibitors: $1 \mathrm{~mm}$ EDTA, $1 \mu \mathrm{g} / \mathrm{ml}$ pepstatin A, $0.4 \mathrm{~mm}$ phenylmethylsulfonyl fluoride, and $0.25 \mathrm{mg} / \mathrm{ml} N$-ethyl maleimide). Tissue homogenates were prepared in a Teflon-on-glass homogenizer, using four strokes of pestle rotation by a Wheaton overhead stirrer (Model 903475, setting 4, Fisher), and centrifuged at $12,000 \times g$ for $30 \mathrm{~min}$. The resulting supernatants were centrifuged at $378,000 \times g$ for $30 \mathrm{~min}$, and the subsequent resulting supernatants were collected as the soluble fractions.

Pellets from the high-speed spin were resuspended in buffer B $[50 \mathrm{mM}$ Tris-HCl, pH 8.0, 0.15 M NaCl, 1\% 3-[(3-cholamidopropyl) dimethyl ammonio]-1-propansulfonate (CHAPS, Boehringer Mannheim), $1 \mathrm{~mm}$ EDTA, $1 \mu \mathrm{g} / \mathrm{ml}$ pepstatin A], homogenized, and centrifuged at $423,500 \times g$ for $40 \mathrm{~min}$. The resulting supernatant was collected as a detergent extract of a crude membrane fraction.

Pellets from the extraction of the membrane fraction were homogenized in $6 \mathrm{~m}$ guanidine- $\mathrm{HCl}, 2 \%$ CHAPS, $50 \mathrm{~mm}$ HEPES, with protease inhibitors, and centrifuged at $423,500 \times g$ for $40 \mathrm{~min}$. The supernatant was dialyzed with $50 \mathrm{~mm}$ Tris, $150 \mathrm{~mm} \mathrm{NaCl}, 6 \mathrm{~m}$ urea, $1 \mathrm{~mm}$ EDTA, and $0.1 \%$ Triton X-100. Soluble, membrane, and guanidine extracts were clarified by $0.2 \mu \mathrm{m}$ filtration.

$P G$ isolation and radioiodination. Samples were applied to columns containing $0.5 \mathrm{ml} / \mathrm{mg}$ protein DEAE Sephacel (Pharmacia, Piscataway, $\mathrm{NJ}$ ) equilibrated in $50 \mathrm{~mm}$ Tris-HCl, $\mathrm{pH} 8.0,0.15 \mathrm{M} \mathrm{NaCl}, 0.5 \%$ CHAPS for anion exchange chromatography. Columns were eluted sequentially with buffers containing high concentrations of $\mathrm{NaCl}$ and urea, and low $\mathrm{pH}$, to elute non-PGs. Column $\mathrm{pH}$ was restored, and PGs were eluted with $50 \mathrm{~mm}$ Tris- $\mathrm{HCl}, \mathrm{pH} 8.0,0.75 \mathrm{M} \mathrm{NaCl}, 0.5 \%$ CHAPS, and batchbound to $100 \mu$ l DEAE Spectragel M (Spectrum Medical Industries, Los Angeles, CA). The matrix was washed with $50 \mathrm{~mm}$ Tris-HCl, pH 8.0, 0.15 $\mathrm{M} \mathrm{NaCl}$, to eliminate any detergent that might interfere with the iodination reaction. Bound PG-containing material was radioiodinated according to the method of Lories et al. (1987), using chloramine T, $5 \mathrm{mCi}$ of ${ }^{125} \mathrm{I}$ (NEN, Boston, MA), and a 3 min reaction time. Unbound ${ }^{125} \mathrm{I}$ was removed by extensive washing, and ${ }^{125}$ I-labeled PGs were eluted.

Enzymatic analysis of PGs. PGs were diluted in $50 \mathrm{~mm}$ Tris-phosphate, $\mathrm{pH} 7.0$, containing protease inhibitors, so that samples contained a final concentration of $<0.2 \mathrm{M} \mathrm{NaCl}$, for efficient enzymatic treatment. GAG lyases were used for $3-4 \mathrm{hr}$ at concentrations of $0.05 \mathrm{U} / \mathrm{ml}$ chondroitinase $\mathrm{ABC}$ at $37^{\circ} \mathrm{C}, 0.2 \mathrm{U} / \mathrm{ml}$ keratinase at $37^{\circ} \mathrm{C}$, or $0.4 \mu \mathrm{g} / \mathrm{ml}$ heparitinase at $43^{\circ} \mathrm{C}$ (heparitinase conditions were determined empirically to give complete digestion of HSPGs without substantial chondroitinase activity). Digests using combinations of lyases were performed at $37^{\circ} \mathrm{C}$. After GAG lyase treatment, samples were analyzed by SDS-PAGE (Laemmli, 1970) under nonreducing conditions. Molecular weights were determined with the use of prestained high molecular weight protein standards (Bio-Rad, Hercules, CA). Gels were fixed, dried, and exposed to Hyperfilm MP (Amersham, Arlington Heights, IL) or a PhosphorImager Screen (Molecular Dynamics, Sunnyvale, CA). The amount of radioactivity in each protein band of the soluble fraction gel was measured by exposing the original gel to a phosphorimaging screen and using Molecular Dynamics ImageQuant software. For the membrane fraction gels, the original film, against which the gel was autoradiographed, was scanned on a flat-bed scanner, and mean pixel values for each protein band and the entire gel lane were measured using the Histogram function of the Adobe Photoshop software program. For all gels, the amount of radioactivity in each band was then expressed as a fraction of the radioactivity in the entire lane.

Metabolic labeling and analysis. Tectal slices were incubated in PBS containing $6.5 \mathrm{gm} / 1$ glucose and no sulfate for $30 \mathrm{~min}$ at $37^{\circ} \mathrm{C}$ in a humidified atmosphere with $5 \% \mathrm{CO}_{2}$. To measure overnight incorporation of sulfate, slices were subsequently cultured in DMEM (Life Technologies) supplemented with $1 \mu \mathrm{g} / \mathrm{ml}$ insulin, $10 \mu \mathrm{g} / \mathrm{ml}$ transferrin, $20 \mathrm{nM}$ progesterone, $100 \mu \mathrm{M}$ putrescine, $30 \mathrm{~nm}$ selenium, $20 \mu \mathrm{g} / \mathrm{ml}$ bovine serum albumin, and $100 \mathrm{U} / \mathrm{ml}$ Pen-G (DMEM+), containing $250 \mu \mathrm{Ci} / \mathrm{ml}{ }^{35} \mathrm{~S}$ sulfate supplemented with unlabeled sulfate to a final concentration of 50 $\mu \mathrm{M}$. For short-term labeling $(1 \mathrm{hr})$, slices were cultured in DMEM+ containing $250 \mu \mathrm{Ci} / \mathrm{ml}{ }^{35} \mathrm{~S}$-sulfate and no additional sulfate. In some experiments, slices were cultured overnight in DMEM + containing both $50 \mu \mathrm{Ci} / \mathrm{ml}^{35} \mathrm{~S}$-sulfate and $30-50 \mu \mathrm{Ci} / \mathrm{ml}^{3} \mathrm{H}$-leucine, with final concentrations of $50 \mu \mathrm{M}$ total sulfate and $80 \mu \mathrm{M}$ total leucine.

For qualitative analysis of ${ }^{35} \mathrm{~S}$-sulfate incorporation into macromolecules, slices that were labeled overnight were rinsed in PBS, fixed in $4 \%$ paraformaldehyde in PBS, dehydrated, mounted on slides, and autora- 
diographed against Hyperfilm MP (Amersham). The film was scanned with an AGFA Duoscan flat-bed scanner, and mean pixel values were measured with the Histogram function of the Adobe Photoshop software program. For specific quantification of incorporation into GAGs (as opposed to sulfated proteins and/or lipids) we used the method of Rapraeger and Yeaman (1989), in which GAGs and PGs are selectively retained on cationic nylon blots in the presence of urea and detergents. Slices labeled with ${ }^{35} \mathrm{~S}$-sulfate alone were rinsed in Gey's balanced salt solution, and 300- $\mu \mathrm{m}$-diameter cores of tissue were collected from either midline or lateral tectum, respectively, using a Neuropunch (Fine Science Tools, Foster City, CA).

Cores from 18 slices were collected in each experiment. In Experiments $1-3$, the 18 midline and 18 lateral tectal cores were each pooled into single samples. Each sample was subsequently split into three aliquots, to examine the reproducibility of the dot-blot protocol for analysis of ${ }^{35} \mathrm{~S}$-sulfate incorporation. In Experiment 3, an aliquot of each sample was used singly for measurement of ${ }^{3} \mathrm{H}$-leucine incorporation. For Experiments $4-7$, the 18 cores were split into three midline and three lateral groups, to assess the reproducibility of the tissue's radiolabel incorporation. Most tissue samples were taken from a region midway between the ventricle and the pial surface (see Fig. 4); in some cases, samples from dorsal and ventral regions of midline and lateral tectum were compared.

Tissue samples were resuspended in $10 \mathrm{~mm}$ Tris- $\mathrm{HCl}, \mathrm{pH} \mathrm{8.0,0.1 \%}$ Triton X-100, with protease inhibitors, and homogenized on ice with a Teflon-on-glass homogenizer. Protein content was determined by amido black binding (Schaffner and Weissman, 1973). Samples were subjected to GAG lyase digestion (conditions as above), then diluted 10 -fold with $10 \mathrm{~mm}$ Tris-HCl, $\mathrm{pH}$ 8.0, $8 \mathrm{~m}$ urea, $0.1 \%$ Triton X-100 (TUT buffer), and boiled for 10 min (Rapraeger and Yeaman, 1989).

Cationic nylon blots (Zeta-probe) and nitrocellulose blots (both from Bio-Rad) were prewetted in $50 \mathrm{~mm}$ Tris- $\mathrm{HCl}, \mathrm{pH}$ 8.0, $0.15 \mathrm{M} \mathrm{NaCl}$ (TBS) for $30 \mathrm{~min}$, and then placed in a dot-blot apparatus (Bio-Rad) with the nitrocellulose overlaying the nylon (the nitrocellulose captures proteins and nucleic acids, preventing them from saturating the nylon). Each well of the dot-blot apparatus was rinsed with TUT buffer, samples containing equivalent amounts of protein $(\leq 0.86 \mu \mathrm{g}$ protein) were pulled through the wells by suction, and the wells were rinsed again with TUT buffer. To avoid saturation of the membranes, no more than $840 \mathrm{ng}$ protein was loaded per dot (Rapraeger and Yeaman, 1989); standard curves prepared using different concentrations of ${ }^{35} \mathrm{~S}$-sulfate-labeled brain homogenates verified that filter binding was linear over the entire range examined. After wells were rinsed, the nylon blot was removed, washed in TBS for $10 \mathrm{~min}$, in TBS with $0.65 \mathrm{M} \mathrm{NaCl}$ for $30 \mathrm{~min}$ (to remove unbound GAG fragments), in TBS for $10 \mathrm{~min}$, in distilled water for $10 \mathrm{~min}$, and in $95 \%$ ethanol for $10 \mathrm{~min}$, dried, and placed against a Phosphor Screen (Molecular Dynamics). The amount of bound ${ }^{35} \mathrm{~S}$ per sample was quantified using the ImageQuant program.

Samples that were labeled with both ${ }^{35} \mathrm{~S}$-sulfate and ${ }^{3} \mathrm{H}$-leucine were collected, and the amount of bound ${ }^{35} \mathrm{~S}$ was analyzed as above. For measurement of bound ${ }^{3} \mathrm{H}$, an aliquot of the initial tissue homogenate was removed, precipitated with trichloroacetic acid onto a cellulose acetate filter, and stained with amido black. That filter was dissolved in $300 \mu \mathrm{l}$ of 2-ethoxyethanol, diluted 1:30 with Liquiscint scintillation fluid, and analyzed with a $\beta$ counter (LKB Model 1217, Wallac, Gaithersburg, MD), using a window of $8-88$. Because the sample measurements included counts attributable to both ${ }^{35} \mathrm{~S}$ and ${ }^{3} \mathrm{H}$, we also measured known amounts of ${ }^{35} \mathrm{~S}$ and ${ }^{3} \mathrm{H}$ in this window and the $100-168$ window and determined the efficiency of counting for each isotope. On the basis of these efficiencies and measurements of ${ }^{35} \mathrm{~S}$ incorporation (either by scintillation counter or by phosphorimager), we found that given the levels of ${ }^{35} \mathrm{~S}$ and ${ }^{3} \mathrm{H}$ incorporation in these experiments, spillover of counts attributable to incorporated ${ }^{35} \mathrm{~S}$ into the lower window was always $<10 \%$ of the total counts in that window. Therefore, we routinely used the counts per minute in the $8-88$ window as a measure of bound ${ }^{3} \mathrm{H}$.

Data were analyzed with the use of an unpaired Student's $t$ test and a Mann-Whitney rank sum test.

Data interpretation. Because it was not possible to cleanly dissect midline tectal tissue away from all lateral tissue, estimations of the amount of lateral contamination were made based on the width of the tissue sample obtained and the actual width of the CS-rich midline region (as measured microscopically after CS-56 staining). Because of such contamination, the observed concentrations of any PG in midline versus lateral tissue samples will differ from the actual concentrations in midline and lateral tissue, according to the equation:

$$
[\mathrm{PG}]_{\mathrm{observed}, \text { midline }}=m[\mathrm{PG}]_{\mathrm{actual}, \text { midline }}+(1-m)[\mathrm{PG}]_{\mathrm{actual}, \text { lateral }},
$$

where $m$ refers to the fraction of the midline sample that is derived from midline tissue.

Calculations of how much the abundance of any given CSPG or group of CSPGs would need to differ between midline and lateral samples to account for observed differences in CS content (assuming no change in the amount of CS per core protein) were made using the following formula:

$$
[\mathrm{CS}]_{\text {midline }} /[\mathrm{CS}]_{\text {lateral }}=\sum_{\mathrm{i}=1}^{n}[\mathrm{CSPG}]_{\mathrm{i}, \text { midline }} / \sum_{\mathrm{i}=1}^{\mathrm{n}}[\mathrm{CSPG}]_{\mathrm{i}, \text { lateral }} \text {, }
$$

where $n$ refers to the number of CSPGs in the tissue. Thus if there are 10 CSPGs in a tissue, and the ratio of midline to lateral CS concentrations is 3 , this ratio could reflect the fact that just one CSPG is 21-fold more abundant at the midline, or two of them are on average 11-fold more abundant, or three of them are on average 7.67-fold more abundant, and so forth down to all 10 being threefold more abundant.

\section{RESULTS \\ CS immunoreactivity is concentrated at the tectal midline}

Although the exact structure of the CS epitope recognized by the CS-56 antibody has not been determined, it is known that the antibody binds specifically to chondroitin 4-sulfates and chondroitin 6-sulfates (Avnur and Geiger, 1984). In coronal sections through the tectum of the neonatal hamster, immunoreactivity with the CS-56 antibody was present at the midline (Fig. $1 A$, arrow), in a dense band that extended between the ventricular surface and the pial surface, with less staining where the intertectal axons course (Fig. 1A, arrowhead). The staining in the midline region was approximately three to seven times more dense than that in the lateral tectum, as measured from immunostained tissue sections, with the dorsal regions containing higher average midline/lateral immunofluorescence ratios than the ventral and middle regions (dorsal, 7:1; middle, 5:1; ventral, 4:1). The CS-56 immunoreactivity at the midline was localized to a similar region as that stained by a monoclonal antibody to vimentin, a marker for specialized raphe glia (Fig. 1B) (see Wu et al., 1995), suggesting that high levels of CS are expressed by these midline glial cells. During development, CS immunoreactivity at the midline was first discernible around embryonic day 15 (data not shown), when retinal axons are growing into the tectum (Jhaveri et al., 1991). Thus, CS is in an appropriate position to play a role in the barrier function of the tectal midline for developing retinal afferents. We sought to identify the core protein that bears the CS that is concentrated at the midline.

\section{Multiple proteoglycans are found in the developing tectum}

To compare the profiles of PG core proteins regionally across the superior colliculus, tissues from midline and lateral tectum were separately dissected and sequentially extracted to remove soluble PGs (extraction in isotonic sucrose), membrane-associated PGs (extraction with nonionic detergent), and insoluble PGs (extraction with $6 \mathrm{M}$ guanidine- $\mathrm{HCl}$ ). From each of these fractions, PGs were isolated by anion exchange chromatography and labeled with ${ }^{125} \mathrm{I}$ according to the procedures of Herndon and Lander (1990).

Because of their GAG chains, PGs normally run as diffuse smears on SDS gels; thus, PG core proteins may be identified as bands that appear in SDS-PAGE only after treatment of samples with GAG-degrading enzymes. Because some PGs contain both CS and HS chains (Rapraeger et al., 1985), in some cases we used a combination of enzymes to identify the GAG types on the tectal 


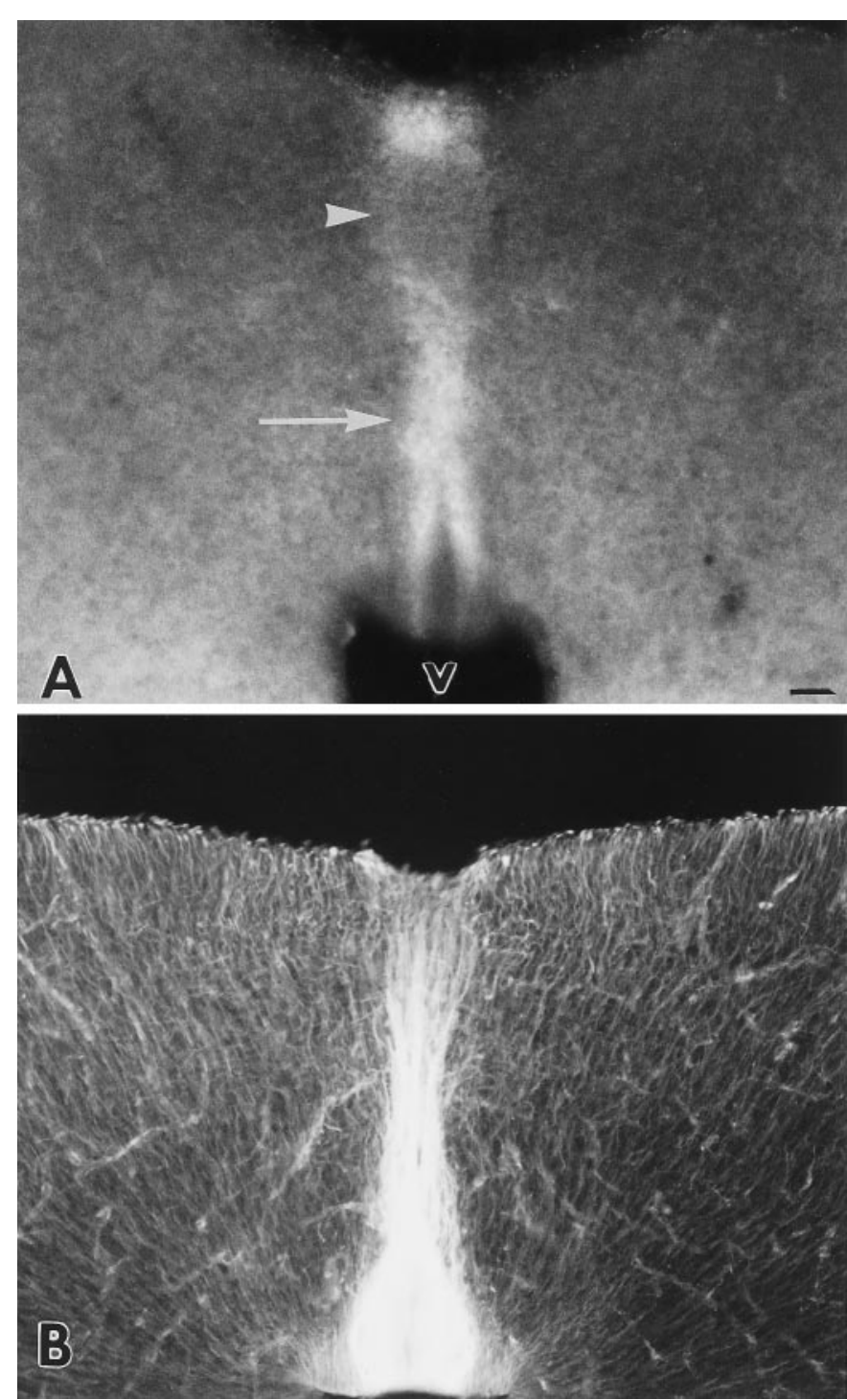

Figure 1. Immunostaining for CS and vimentin in coronal sections, 30 $\mu \mathrm{m}$ thick, through the tectum of the developing Syrian hamster at age P0. $A$, Section stained with monoclonal antibody CS-56, against chondroitin sulfate. Staining is concentrated in the midline region (arrow), in a band that extends between the ventricle and the pial surfaces. Note the lighter staining in the dorsal midline (arrowhead) where intertectal axons cross to the opposite side. $V$, Ventricle. $B$, Section stained with a monoclonal antibody against vimentin. Dense immunoreactivity is visible in midline cells, with more staining near the ventricle where the cell bodies of the midline glia lie. Scale bar, $50 \mu \mathrm{m}$.

PGs. In all cases, protease inhibitors were included during GAG lyase digestion, to prevent the misidentification of proteolytic breakdown products as PG cores.

A total of 17 protein cores were identified in tectal homogenates, most in the soluble and membrane fractions. The soluble fraction contained an HSPG with a core protein of $\sim 121 \mathrm{kDa}$ and nine CSPGs with core proteins of $\sim 293,269,241,215,211,156$, 132,114 , and $86 \mathrm{kDa}$ (Fig. $2 A$ ). In the membrane fraction, we detected two HSPGs with core proteins of $\sim 137$ and $67 \mathrm{kDa}$, and four CSPGs with core proteins of $\sim 288,272,246$, and $215 \mathrm{kDa}$ (Fig. 2B). In a few cases, digestion of the membrane fraction with keratinase showed a keratin sulfate (KS) PG core protein of $\sim 140 \mathrm{kDa}$, but this result could not be consistently reproduced (data not shown). The guanidine-extracted material contained an HSPG of $\sim 125 \mathrm{kDa}$ (data not shown). Both membrane and soluble fractions also contained several non-PG proteins, as evidenced by sharp protein bands not affected by GAG lyases. These may be either highly anionic proteins or proteins that associate and copurify with PGs (Herndon and Lander, 1990).

\section{Comparison of PG cores derived from midline and lateral tectum}

As shown in Figure 2, the profiles of core proteins derived from midline and lateral tectum were very similar. Each PG core isolated from the midline region of the tectum was also found in the lateral region, and vice versa. This was true of PGs isolated from soluble fractions, membrane fractions, and guanidine extracts. When the amount of radioactivity in each PG core protein band was quantified and expressed as a fraction of the total radioactivity in the entire sample lane, the measurements suggested that most cores were expressed at similar relative levels in midline and lateral tectal fractions (Table 1).

On the basis of differences in CS-56 immunofluorescence, we had expected the SDS-PAGE analysis to yield at least one CSPG that was present predominantly at the midline, and much less so (or not at all) in the lateral tectum. Because this turned out not to be so, we considered whether the higher amount of CS at the midline might be attributable either to increased expression of all PG core proteins at the midline or, more likely, to increased CS glycosylation at the midline of one or more of the protein cores that are present in both regions.

\section{GAG biosynthesis is specifically elevated at the tectal midline}

Because GAGs are so highly sulfated, they usually account for the majority of sulfate incorporation by tissues. We therefore initially surveyed GAG metabolism across the tectum by allowing tissue slices to incorporate ${ }^{35} \mathrm{~S}$-sulfate in vitro and by using autoradiography to quantify radioactivity at different positions within the slices. For these experiments, coronal slices through the midbrains of P0 hamster pups were used. As Figure 3 shows (arrow), ${ }^{35} \mathrm{~S}$-sulfate incorporated during $18 \mathrm{hr}$ in vitro was concentrated at the tectal midline in a pattern similar to that seen with CS-56 immunostaining (Fig. 1A). Although some ${ }^{35} \mathrm{~S}$-sulfate had been incorporated in every part of the slice, the midline area contained radiolabel in a dense band between the ventricular and pial surfaces, at a level $\sim 1.6$ times the density of radiolabel in lateral areas. In Figure 3, the midline band measures $\sim 90 \mu \mathrm{m}$ in width, wider than the $\sim 50 \mu \mathrm{m}$ band of CS-56 immunoreactivity seen in Figure $1 A$. This discrepancy is expected, however, because of the much greater thickness $(300 \mu \mathrm{m})$ of tissue slices used in metabolic labeling experiments. Because radioactivity incorporated into tissue slices emits energy in all directions, midline radioactivity not at the very surface of the slice should significantly expose the autoradiographic emulsion at a substantial distance from the actual midline. This effect should give rise to a midline band that appears thicker and contains a more diluted ${ }^{35} \mathrm{~S}$ signal than the true midline. (This effect should be partially mitigated for the deepest sources of radioactivity because of adsorption of radioactive particles by the intervening tissue itself).

To more precisely measure changes in GAG metabolism in different parts of the tectum, experiments were next performed in which midline and lateral samples of metabolically labeled tissue slices were isolated and the amount of macromolecular radioactivity directly quantified. Because metabolic labeling allowed us 
P0 Soluble

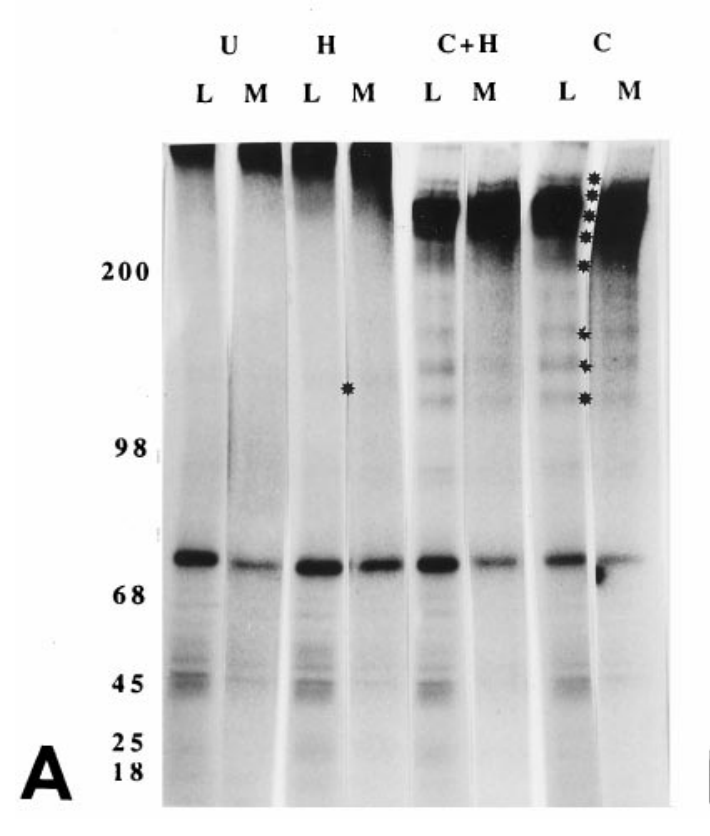

P0 Membrane

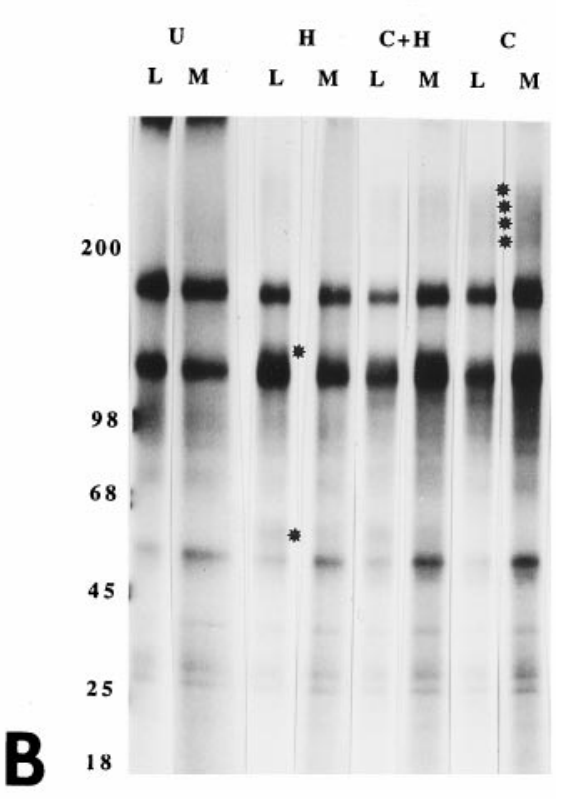

Figure 2. SDS-PAGE analysis of hamster PGs from P0 midline and lateral tectum. Radioiodinated PGs from soluble $(A)$ and membrane fractions $(B)$ of midline and lateral tectum were treated with GAG lyases and analyzed on $5-15 \%$ exponential gradient gels. To compensate for unequal loading (samples from lateral tectum had a higher concentration of radioactivity), autoradiograms were photographed and printed under two different conditions, and a single composite figure was generated that best shows all PG cores that could be readily observed on the original autoradiograms. $L$, Lateral tectum; $M$, midline tectum; $U$, no enzyme; $H$, heparatinase; $C$, chondroitinase ABC. Numbers are molecular weight standards, in kilodaltons. Asterisks denote putative PG core proteins.

Table 1. PG cores are expressed at similar relative levels in midline and lateral tectum

\begin{tabular}{|c|c|c|c|c|}
\hline \multirow{2}{*}{$\begin{array}{l}\text { GAG } \\
\text { type }\end{array}$} & \multirow{2}{*}{$\begin{array}{l}\text { Brain } \\
\text { fraction }\end{array}$} & \multirow{2}{*}{$\begin{array}{l}\text { Core protein } \\
\text { molecular weight }(\mathrm{kD})\end{array}$} & \multicolumn{2}{|c|}{ (\% of lane's radioactivity) } \\
\hline & & & Lateral & Midline \\
\hline $\mathrm{CS}$ & Soluble & 293 & 2.1 & 1.36 \\
\hline CS & Soluble & 269 & 1.9 & 1.56 \\
\hline $\mathrm{CS}$ & Soluble & 241 & 1.06 & 1.4 \\
\hline $\mathrm{CS}$ & Soluble & 215,211 & 1.2 & 1.4 \\
\hline $\mathrm{CS}$ & Soluble & 156 & 1.0 & 1.3 \\
\hline $\mathrm{CS}$ & Soluble & 132 & 1.8 & 1.8 \\
\hline $\mathrm{CS}$ & Soluble & 114 & 1.7 & 1.8 \\
\hline $\mathrm{CS}$ & Soluble & 86 & 1.2 & 0.76 \\
\hline $\mathrm{CS}$ & Membrane & $288,272,246$ & 1.18 & 1.04 \\
\hline $\mathrm{CS}$ & Membrane & 215 & 1.27 & 1.29 \\
\hline HS & Membrane & 137 & 1.30 & 1.38 \\
\hline HS & Membrane & 67 & 1.19 & 1.48 \\
\hline
\end{tabular}

Radioactivity of putative protein cores, each (one to three gel bands) expressed as a fraction of the total radioactivity of the PG sample (one gel lane). All observed putative PG core bands were analyzed except for the soluble HSPG band, which was too faint to measure accurately. In a few cases, because their spatial proximity prohibited accurate resolution of the single bands, two to three of the high molecular weight CSPG bands were measured together.

to measure GAG-containing macromolecules with greater sensitivity, it was possible in these experiments to dissect more restricted regions from these slices than had been practicable when analyzing PG core proteins. We used a Neuropunch to harvest $300-\mu \mathrm{m}$-diameter cylinders of tissue from specific regions of slices (Fig. 4), pooled pieces from equivalent regions, solubilized the tissue, and specifically captured PGs and GAGs using a filterbinding method (Rapraeger and Yeaman, 1989). Because the midline accumulation of CS immunoreactivity appears to be $\sim 50$ $\mu \mathrm{m}$ in width, even the $300 \mu \mathrm{m}$ cylinders isolated using the Neuropunch should be significantly contaminated with nonmidline tissue. Despite this contamination, we were able to observe differences in ${ }^{35} \mathrm{~S}$-sulfate incorporation by midline as compared with lateral tectal tissue, with statistical significance when the data were pooled, and in four out of six individual experiments (Table 2, Experiments 1-6). In each experiment, treat- ment of the homogenized tissue samples with a combination of chondroitinase ABC and heparitinase suggested that CS and HS together contribute $\sim 66 \%$ of the labeled GAG in both midline and lateral tectum (data not shown).

Tectal midline samples contained $\sim 1.54 \pm 0.2$ times the GAG ${ }^{35} \mathrm{~S}$-sulfate as that found in samples from lateral tectum (Table 2). As expected because of the contamination of midline samples with lateral tissue, midline/lateral ratios of ${ }^{35} \mathrm{~S}$-sulfate incorporation were lower in the dorsal-most region of the tectum (Table 2, Experiment 7), where CS is expressed in a thinner, $\sim 30-\mu \mathrm{m}$ wide, midline region, and where fascicles of intertectally projecting axons are coursing. The ratios were higher in ventral tectum (Table 2, Experiment 7), where CS is expressed in a wider ( $\sim 60$ $\mu \mathrm{m})$ midline region.

The above results could reflect the possibility that in tectal slice cultures, midline tissue is more metabolically active per unit 


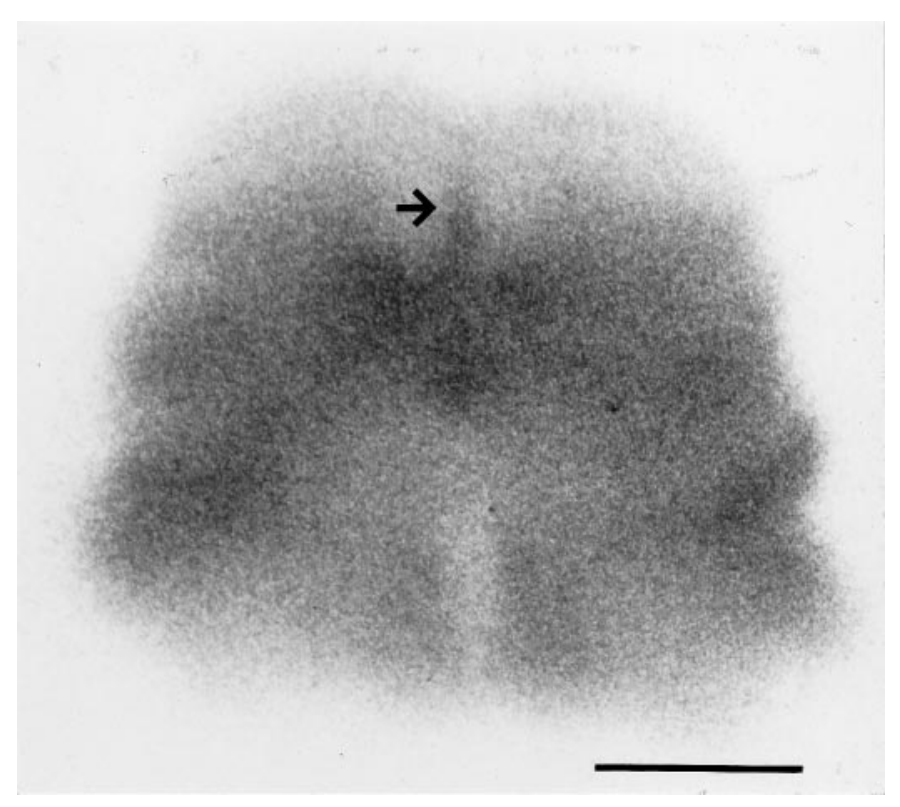

Figure 3. Metabolic labeling of $\mathrm{P} 0$ hamster tectum. A living tissue slice (coronal plane, $300 \mu \mathrm{m}$ thickness) through the midbrain of a P0 hamster was incubated for $18 \mathrm{hr}$ with ${ }^{35} \mathrm{~S}$-sulfate. A dense group of cells along the tectal midline (arrow) have incorporated the radiolabel. Scale bar, $1 \mathrm{~mm}$.

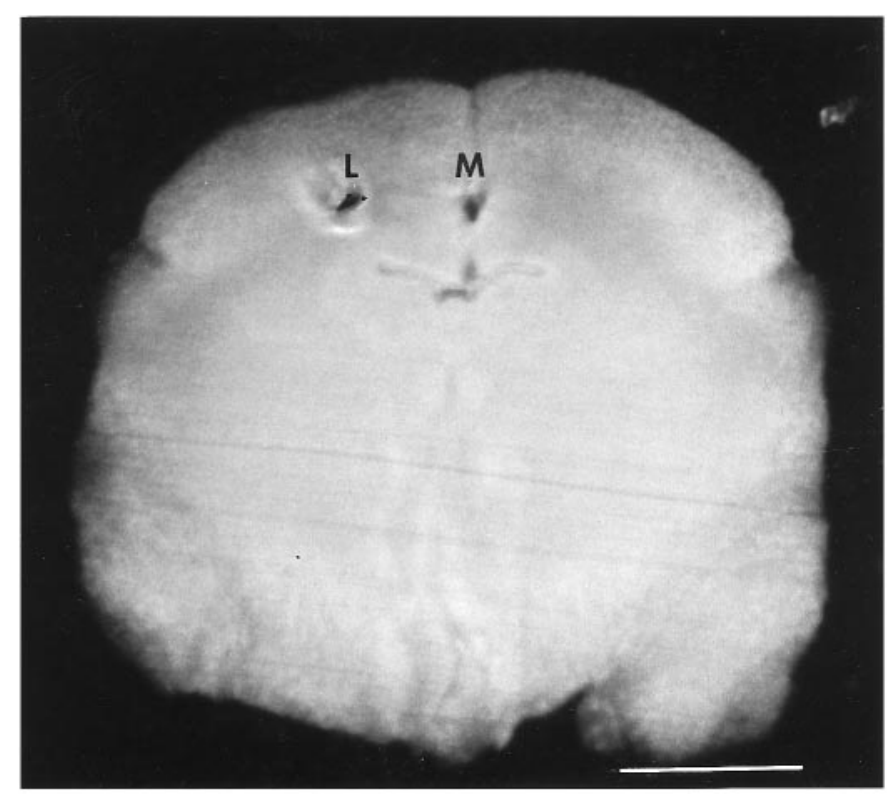

Figure 4. Coronal tissue slice of $300 \mu \mathrm{m}$ thickness through P0 hamster midbrain, showing the position and size of tissue dissected with a Neuropunch of $300 \mu \mathrm{m}$ diameter, to access midline $(M)$ and lateral $(L)$ cores of tectal tissue. Scale bar, $1 \mathrm{~mm}$.

volume, perhaps because cell density is greater or in vitro cell survival is higher, than in lateral tectum. To test this possibility, we also performed experiments in which tectal tissue slices were incubated with both ${ }^{3} \mathrm{H}$-leucine and ${ }^{35} \mathrm{~S}$-sulfate, permitting a measure of relative protein synthesis in the same tectal regions in which sulfate incorporation was assessed. As shown in Table 2, ${ }^{3} \mathrm{H}$-leucine incorporation was not significantly different between midline and lateral regions (Table 2, Experiments 3 and 4). Therefore, regional differences in sulfate incorporation are not simply reflective of a general difference in overall metabolic activity.

The demonstration of increased overnight incorporation of ${ }^{35} \mathrm{~S}$-sulfate in the tectal midline indicates a greater net production of sulfated molecules during the labeling period; however, the result itself does not distinguish between a higher rate of GAG synthesis or lower rate of GAG degradation. To examine this question, we labeled tectal slices with ${ }^{35} \mathrm{~S}$-sulfate for a short period of time, $1 \mathrm{hr}$, during which degradation would be expected to be less significant (Table 2, Experiments 5 and 6). We saw essentially the same results as with overnight labeling. We conclude that tectal midline cells synthesize more sulfated GAG per unit time than do cells of the lateral tectum.

\section{DISCUSSION}

In the present study we have examined the expression and synthesis of $\mathrm{CS}$ in the tectum during the time that retinal axons are entering the tectal target. CS expression was found to be strongly concentrated at the tectal midline at this time (Fig. 1). Surprisingly, biochemical analysis of tectal PGs revealed similar CSPG and HSPG core protein profiles in both midline and lateral tectal areas (Fig. 2, Table 1). This result led to the hypothesis that the midline concentration of CS arises because of differences in the amount of CS, but not CSPG core proteins, in midline versus lateral tectum. Results of metabolic labeling experiments support this hypothesis (Fig. 3, Table 2) and further show that the rate of CS synthesis is elevated at the tectal midline. Taken together with evidence that the tectal midline acts as a barrier for growing retinal axons, these results suggest that differences in PG glycosylation may play a role in establishing a boundary to axonal growth.

\section{CS is concentrated at the tectal midline, a putative barrier to retinal axon growth}

As developing retinal axons elongate into the superior colliculus, some of them course near the specialized raphe glia of the tectal midline, but normally do not cross the midline, unless the raphe glia have been previously removed or damaged (Schneider, 1973; So and Schneider, 1978; Poston et al., 1988; Wu et al., 1995; Jhaveri et al., 1996). In contrast, at an earlier stage of development, intertectal afferent fibers freely cross the tectal midline (Jhaveri, 1993a; Jhaveri and Hoffman-Kim, 1996). Here we report that strong CS-56 immunoreactivity appears at the tectal midline after the crossing of intertectal afferents and shortly after the time retinal axons begin to invade the tectum. Thus, the appearance of a midline accumulation of CS correlates with the appearance of an apparent barrier to axon growth. A potentially related set of observations has been made in the roofplate of the developing spinal cord, a midline structure broadly analogous to the specialized glia seen at the tectal midline. CS immunoreactivity at the spinal cord roofplate is high at a time when dorsal column fibers elongate near to but distinctly avoid the midline, and it decreases at a later stage, when axons of the dorsal spinal commissure grow across the midline (Snow et al., 1990a; Pindzola et al., 1993).

Our observations of lower levels of CS-56 immunoreactivity in the lateral versus midline tectum contrast with a recent study in which strong CS-56 staining was reported in retinorecipient layers of the chick midbrain during the time of retinotectal axon ingrowth (McAdams and McLoon, 1995), perhaps reflecting species-specific differences in molecular expression. In support of this notion, CS expression has also been observed in the chick central retina when and where axons of retinal ganglion cells 


\begin{tabular}{|c|c|c|c|c|c|}
\hline $\begin{array}{l}\text { Labeling } \\
\text { time }\end{array}$ & $\begin{array}{l}\text { Brain } \\
\text { region }\end{array}$ & $\begin{array}{l}{ }^{35} \mathrm{~S} \text {-sulfate } \\
(\mu \mathrm{Ci} / \mathrm{ml})\end{array}$ & $\begin{array}{l}{ }^{35} \mathrm{~S} \text {-sulfate in- } \\
\text { corporation } \\
(\mathrm{M} / \mathrm{L})\end{array}$ & $\begin{array}{l}{ }^{3} \mathrm{H} \text {-leucine } \\
(\mu \mathrm{Ci} / \mathrm{ml})\end{array}$ & $\begin{array}{l}{ }^{3} \mathrm{H} \text {-leucine } \\
\text { incorporation } \\
(\mathrm{M} / \mathrm{L})\end{array}$ \\
\hline 1. $\mathrm{O} / \mathrm{N}$ & Middle & 250 & $1.44 \pm 0.58$ & & \\
\hline 2. $\mathrm{O} / \mathrm{N}$ & Middle & 250 & $1.79 \pm 0.12^{* * *}$ & & \\
\hline 3. $\mathrm{O} / \mathrm{N}$ & Middle & 50 & $1.38 \pm 0.06^{* * *}$ & 50 & 1.12 \\
\hline 4. $\mathrm{O} / \mathrm{N}$ & Middle & 50 & $1.47 \pm 0.38^{*}$ & 30 & $1.07 \pm 0.24$ \\
\hline $5.1 \mathrm{hr}$ & Middle & 250 & $1.79 \pm 0.71^{*}$ & & \\
\hline 6. $1 \mathrm{hr}$ & Middle & 250 & $1.34 \pm 0.49$ & & \\
\hline 7. $\mathrm{O} / \mathrm{N}$ & Dorsal & 250 & $0.90 \pm 0.39$ & & \\
\hline 7. $\mathrm{O} / \mathrm{N}$ & Ventral & 250 & $2.30 \pm 1.0^{* *}$ & & \\
\hline
\end{tabular}

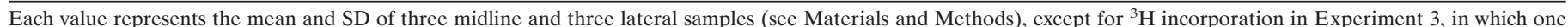

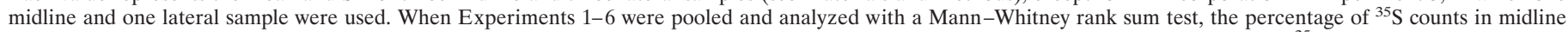

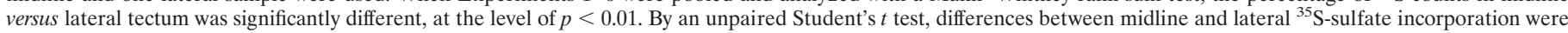

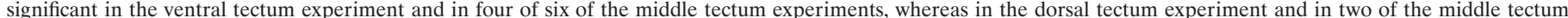

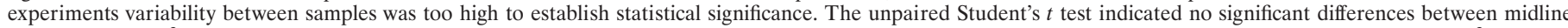

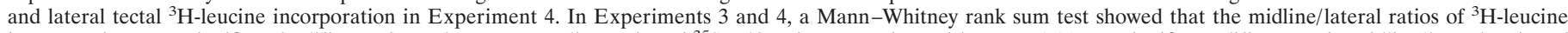



${ }^{35}$ S-sulfate incorporation between Experiments 1 through 6 were observed by a Mann-Whitney rank sum test. M, Midline; L, lateral; O/N, overnight.

$* p<0.05 ; * p<0.02 ; * * p<0.001$.

elongate (Snow et al., 1991; Ring et al., 1995), whereas in mouse and rat retina, $\mathrm{CS}$ is absent from regions where the axons are growing (Snow et al., 1991; Brittis et al., 1992). In addition, although many CSPGs are stained by CS-56, it is always possible that this antibody does not react with every CSPG in the hamster tectum.

\section{The developing hamster tectum contains a diverse group of PGs}

As previously observed in rat brain (Herndon and Lander, 1990) and mouse cerebral cortex (Emerling and Lander, 1996), the early postnatal hamster tectum contains a diverse set of CS and HSPGs. As also seen in tissue from whole brains of adult rats, most CSPGs appear in the soluble fraction of developing tectal tissue, whereas most HSPGs are found in the membrane fraction. Most of the PG core proteins observed in the tectum have molecular weights and GAG compositions similar to those of PG core proteins that have been reported by others in developing rat, cow, or chicken brain; these similarities are summarized in Table 3. Some tectal CSPGs (core proteins of 272, 246, and $215 \mathrm{kDa}$ in the membrane fraction and 293 and $269 \mathrm{kDa}$ in the soluble fraction) do not correlate directly to known PGs; however, the existence of additional, uncharacterized PG cores of $>200 \mathrm{kDa}$ in rat and cow brain has been reported previously (Herndon and Lander, 1990; Yamada et al., 1994).

\section{Midline and lateral PGs have similar protein cores but differ in amount or sulfation of GAGs}

Because CS is normally carried by PG core proteins, we had anticipated that the high concentration of CS immunoreactivity at the tectal midline of the hamster would reflect the specific expression of a particular CSPG core protein at the midline. However, we found no substantial differences in the patterns of core proteins, whether CS- or HS-bearing, between midline and lateral tectal regions. The small differences in relative expression of any particular core protein that were documented (Fig. 2, Table 1) would not have been great enough to account for the three- to sevenfold difference in CS immunoreactivity between midline and lateral tectum. For example, if we make the assumption that each of the 13 CSPGs isolated from the tectum contains a similar amount of $\mathrm{CS}$, then for differences in expression of any one
CSPG to produce a three- to sevenfold difference in CS-56 immunoreactivity between midline and lateral tectum, that CSPG would have to be $\sim 27-79$ times more abundant in midline than lateral tectum (see Materials and Methods). Because our dissection technique for $\mathrm{PG}$ isolation resulted in midline pieces that were $\sim 500 \mu \mathrm{m}$ in width, $\sim 10$ times the width of the stripe of CS-56 immunostaining at the midline, we anticipate a $90 \%$ contamination of tectal midline PGs with lateral PGs. Thus, a PG that is 27- to 79-fold enriched at the midline should have shown an increase of 3- to 9.8-fold in relative abundance in our preparations, a difference that would have been readily apparent by SDS-PAGE analysis. If, on the other hand, more than one PG core is specifically enriched at the midline, a smaller difference would be seen. For example, if three CSPGs equally account for the difference between midline and lateral tectum, then each would have to be 9.7- to 27-fold more abundant at the midline, which would imply a 1.9- to 3.6-fold increase in relative abundance in our preparations, still within our limits of detection.

Because we failed to obtain evidence that the accumulation of $\mathrm{CS}$ at the tectal midline could be explained by the increased expression of one or a few PG core proteins, subsequent experiments were aimed at determining whether the increased expression of CS at the midline could be detected by metabolic labeling. In these experiments, we were able to detect a substantial difference in the incorporation of ${ }^{35} \mathrm{~S}$-sulfate into macromolecules in general (Fig. 3), and into GAGs in particular (Table 2), between midline and lateral tectum. When we quantified incorporation of ${ }^{35} \mathrm{~S}$-sulfate into GAG for midline and lateral regions, we measured a ratio of approximately 1.5:1 (Table 2, midline/lateral).

Use of the Neuropunch provides cylindrical tissue samples that are $300 \mu \mathrm{m}$ in diameter; thus, we estimate that $80 \%$ of the "midline" tissue harvested with use of the Neuropunch is composed of lateral tissue, whereas only $20 \%$ consists of midline cells from the $50-\mu \mathrm{m}$-wide stripe of high CS immunoreactivity. Consequently, the 1.5:1 ratio in sulfate incorporation between midline and lateral tectum most likely reflects a true ratio of approximately 3.5:1. This value agrees with our estimates, from immunofluorescence measurements, of the ratio of CS content between midline and lateral tissue (between 3:1 and 7:1; see Results). It is also consistent with data obtained in a recent study by Garcia- 


\begin{tabular}{|c|c|c|c|c|}
\hline GAG type & Fraction & $\begin{array}{l}\text { Hamster tectum core } \\
\text { molecular weight }(\mathrm{kD})\end{array}$ & $\begin{array}{l}\text { Known PG core } \\
\text { molecular weight }(\mathrm{kD})\end{array}$ & Name; reference \\
\hline $\mathrm{CS}$ & Membrane & 288 & 300 , rat & NG2; Levine, 1994 \\
\hline $\mathrm{CS}$ & Soluble & 241 & 235 , rat & S2; Herndon and Lander, 1990 \\
\hline CS & Soluble & 215 & 210, chick & 9BA12; Ring et al., 1995 \\
\hline CS & Soluble & 211 & 210, chick & 9BA12; Ring et al., 1995 \\
\hline $\mathrm{CS}$ & Soluble & 156 & 173, rat & Phosphacan; Maurel et al., 1994 \\
\hline HS & Membrane & 137 & 120 , rat & Syndecan-3; Gould et al., 1995 \\
\hline $\mathrm{CS}$ & Soluble & 132 & 145 , cow & Brevican, full-length; Yamada et al., 1994 \\
\hline CS & Soluble & 132 & 136 , rat & Neurocan; Rauch et al., 1992 \\
\hline CS & Soluble & 114 & 110 , rat & S6; Herndon and Lander, 1990 \\
\hline $\mathrm{CS}$ & Soluble & 86 & 80 , cow & Brevican, truncated; Yamada et al., 1994 \\
\hline HS & Membrane & 67 & 60 , rat & Glypican; Litwack et al., 1994 \\
\hline
\end{tabular}

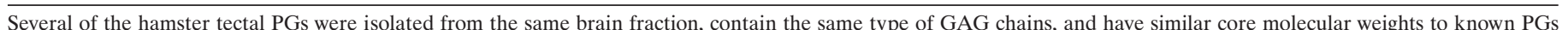

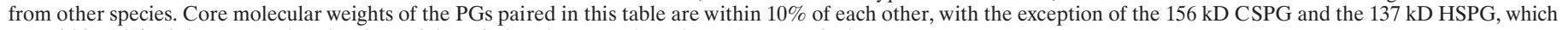
are within $15 \%$ of the reported molecular weights of phosphacan and syndecan-3, respectively.

Abreu et al. (1996), in which the authors labeled dissociated embryonic mouse astrocytes from the middle and lateral half of the mesencephalon with ${ }^{35} \mathrm{~S}$-sulfate overnight, and isolated the labeled GAGs. GAGs isolated from the midline astrocytes contained approximately twice as much ${ }^{35}$ S-labeled CS and HS as those isolated from the lateral astrocytes. Those data suggest that the differences in GAG biosynthetic properties detected here may be intrinsic properties of midline and lateral glial cells, properties that persist even when those cells are removed from their normal tissue environment.

\section{Possible mechanisms underlying positional differences in GAG synthesis}

Several mechanisms could lead to a higher rate of GAG synthesis at the tectal midline. Although it is still formally possible that midline cells make a larger amount of PG core proteins, as described above there would have to be similar increases in the synthesis of most or all of the many CSPG core proteins in order not to change the relative levels of individual cores (compare Table 1). In addition, our results demonstrate that increased GAG synthesis at the midline is attributable to increased production not just of CS but also of HS (because ${ }^{35} \mathrm{~S}$-sulfate incorporation into GAGs was elevated at the midline, but the proportions of radioactivity found as CS and HS were similar to those found in lateral tissue). Furthermore, it has also been reported that the GAG KS is concentrated at the tectal midline (Snow et al., 1991; Hoffman et al., 1994). Thus for increased core protein synthesis to explain the data, one would have to postulate increased synthesis of HSPG and KSPG, as well as CSPG cores at the midline.

More likely is the possibility that cells at the tectal midline synthesize higher levels of sulfate-labeled GAG per core protein than do cells in the lateral tectum. This could be because more GAG chains are initiated per core protein, longer GAG chains are produced, or the GAG chains are more highly sulfated. Such differences result from the regulation of specific biosynthetic enzymes. Larger numbers of GAG chains could reflect increased levels of xylosyl transferase, which initiates CS, HS, and many KS chains; longer chains could be attributable to increased levels of the co-polymerases that extend those chains, and higher levels of sulfation could reflect increased levels of various sulfotransferases. Additionally, increased levels of substrates for these enzymes, nucleotide sugars and 3 '-phosphoadenylylphosphosulfate (PAPS), could also be involved.
Given that we have observed elevations in the synthesis of two GAGs, CS and HS, at the tectal midline - and that $\mathrm{KS}$ is concentrated there as well-the simplest explanation for all of the data is that a biosynthetic pathway common to the production of all three GAG types is the object of regulation in midline cells. These would be the enzyme systems involved in sulfate uptake, PAPS formation, UDP-sugar formation, or xylosylation of core proteins. As the identification and cloning of the enzymes involved in these steps is completed, it will be interesting to determine whether any are differentially expressed in midline versus lateral tectal glial cells.

\section{What role do CSPGs play in the barrier function of the tectal midline?}

Several studies support the idea that the tectal midline acts as a barrier to maintain the laterality of developing retinotectal axons (Schneider, 1973; So and Schneider, 1978; Poston et al., 1988; Wu, 1991; Wu et al., 1995; for review, see Jhaveri, 1993a; Jhaveri and Hoffman-Kim, 1996). Concentrations of CS and/or CSPGs have been seen at a number of potential boundary regions besides the tectal midline, including the posterior sclerotome, perinotochordal mesenchyme, and pelvic girdle precursor (Oakley and Tosney, 1991; Perris et al., 1991; Landolt et al., 1995), the dorsal root entry zone (Pindzola et al., 1993), the spinal cord roofplate (Snow et al., 1990a; Oakley and Tosney, 1991; Oakley et al., 1994), and the retina (Brittis et al., 1992). These observations, together with the ability of some CSPGs to inhibit neurite outgrowth in vitro (e.g., Snow and Letourneau, 1992), suggest that CSPGs play a causal role in restricting axon growth at barrier regions.

If CSPG(s) do have such a function in the tectum, then our results suggest that it is CS itself, and not the protein core, that is responsible. This view agrees with that suggested by in vitro studies in which enzymatic removal of CS chains from retinal explants or forebrain slices allows axons to grow into previously avoided territories (Brittis et al., 1992; Emerling and Lander, 1996). Nonetheless, it is unlikely that CS itself is an obligate inhibitor of axon growth, because many regions in which axons preferentially grow in vivo are enriched in CS (Flaccus et al., 1991; Sheppard et al., 1991; Bicknese et al., 1994; Ring et al., 1995). A more likely model is that CS collaborates with other molecules to produce axon inhibitory signals. One way CS could do that is to act as an extracellular matrix binding site to which 
inhibitory molecules attach (Emerling and Lander, 1996). It will be interesting to determine whether the underlying explanation for increased GAG biosynthesis at the tectal midline is to enable midline cells to concentrate and present various kinds of molecules that act as guidance cues.

\section{REFERENCES}

Avnur Z, Geiger B (1984) Immunocytochemical localization of native chondroitin-sulfate in tissues and cultured cells using specific monoclonal antibody. Cell 38:811-822.

Bicknese AR, Sheppard AM, O'Leary DDM, Pearlman AL (1994) Astroglial differentiation in the opossum superior colliculus. Glia 2:103-111.

Braunewell KH, Martini R, LeBaron R, Kresse H, Faissner A, Schmitz B, Schachner M (1995) Up-regulation of a chondroitin sulphate epitope during regeneration of mouse sciatic nerve: evidence that the immunoreactive molecules are related to the chondroitin sulphate proteoglycans decorin and versican. Eur J Neurosci 7:792-804.

Brittis PA, Silver J (1994) Exogenous glycosaminoglycans induce complete inversion of retinal ganglion cell bodies and their axons within the retinal neuroepithelium. Proc Natl Acad Sci USA 91:7539-7542.

Brittis PA, Canning DR, Silver J (1992) Chondroitin sulfate as a regulator of neural patterning in the retina. Science 255:733-736.

Dou CL, Levine JM (1994) Inhibition of neurite growth by NG2 chondroitin sulphate proteoglycan. J Neurosci 14:7616-7629.

Emerling D, Lander AD (1996) Inhibitors and promoters of thalamic neuron adhesion and outgrowth in embryonic neocortex: functional association with chondroitin sulfate. Neuron 17:1089-1100.

Faissner A, Clement A, Lochter A, Streit A, Mandl C, Schachner M (1994) Isolation of a neural chondroitin sulfate proteoglycan with neurite outgrowth promoting properties. J Cell Biol 126:783-799.

Fernaud-Espinosa I, Nieto-Sampedro M, Bovolenta P (1994) Differential effects of glycosaminoglycans on neurite outgrowth from hippocampal and thalamic neurons. J Cell Sci 107:1437-1448.

Fichard A, Verna JM, Olivares J, Saxod R (1991) Involvement of a chondroitin sulfate proteoglycan in the avoidance of chick epidermis by dorsal root ganglia fibers: a study using beta-D-xyloside. Dev Biol 148:1-9.

Flaccus A, Janetzko A, Tekotte H, Margolis RK, Margolis RU, Grumet M (1991) Immunocytochemical localization of chondroitin 4- and 6-sulfates in developing rat cerebellum. J Neurochem 56:1608-1615.

Garcia-Abreu J, Silva LCF, Tovar FF, Onofre GR, Cavalcante LA, Moura Neto V (1996) Compartmental distribution of sulfated glycosaminoglycans in lateral and medial midbrain astroglial cultures. Glia 17:339-344.

Gould SE, Upholt W, Kosher RA (1995) Characterization of chicken syndecan-3 as a heparan sulfate proteoglycan and its expression during embryogenesis. Dev Biol 168:438-451.

Herndon ME, Lander AD (1990) A diverse set of developmentally regulated proteoglycans is expressed in the rat central nervous system. Neuron 4:949-961.

Hoffman D, Lander AD, Jhaveri S (1994) Isolation of proteoglycans from the developing superior colliculus of the Syrian hamster. Soc Neurosci Abstr 20:1294.

Hoffman-Kim D, Lander AD, Jhaveri S (1995) Metabolic labeling of glycosaminoglycans in the developing tectum of the Syrian hamster. Soc Neurosci Abstr 21:1295.

Hoffman-Kim D, Lander AD, Jhaveri S (1996) Regional differences in tectal chondroitin sulfate expression reflect differential rates of glycosaminoglycan biosynthesis. Soc Neurosci Abstr 22:34.

Huxlin KR, Jervie Sefton A, Schulz M, Bennett MR (1993) Effect of proteoglycan purified from rat superior colliculus on the survival of murine retinal ganglion cells. Dev Brain Res 74:207-217.

Huxlin KR, Carr R, Schulz M, Jervie Sefton A, Bennett MR (1995a) Trophic effect of collicular proteoglycan on neonatal rat retinal ganglion cells in situ. Dev Brain Res 84:77-88.

Huxlin KR, Dreher B, Chulz M, Jervie Sefton A, Bennett MR (1995b) Effect of collicular proteoglycan on the survival of adult rat retinal ganglion cells following axotomy. Eur J Neurosci 7:96-107.

Iijima N, Oohira A, Mori T, Kitabatake K, Kohsaka S (1991) Core protein of chondroitin sulfate proteoglycan promotes neurite outgrowth from cultured neocortical neurons. J Neurochem 56:706-708.

Jhaveri S (1993a) Midline glia of the tectum: a barrier for developing retinal axons. Perspect Dev Neurobiol 1:237-243.
Jhaveri S (1993b) Proteoglycan expression by tectal midline glia in relation to the growth of retinotectal and intertectal axons in developing hamsters. Soc Neurosci Abstr 19:1086.

Jhaveri S, Hoffman-Kim D (1996) Unilateral containment of retinal axons by tectal glia: a possible role for sulfated proteoglycans. Prog Brain Res 108:135-148.

Jhaveri S, Schneider GE, Erzurumlu RS (1991) Axonal plasticity in the context of development. In: Vision and visual dysfunction, Vol 11 (Cronly-Dillon JR, ed), pp 232-240. London: Macmillan.

Jhaveri S, Erzurumlu RS, Schneider GE (1996) The optic tract in embryonic hamsters: fasciculation, defasciculation and other rearrangements of retinal axons. Vis Neurosci 13:359-374.

Junghans U, Koops A, Westmeyer A, Kappler J, Jeyer HE, Muller HW (1995) Purification of a meningeal cell-derived chondroitin sulphate proteoglycan with neurotrophic activity for brain neurons and its identification as biglycan. Eur J Neurosci 7:2341-2350.

Kalb RG, Hockfield S (1990) Induction of a neuronal proteoglycan by the NMDA receptor in the developing spinal cord. Science 250:294-296.

Katoh-Semba R, Oohira A (1993) Core proteins of soluble chondroitin sulfate proteoglycans purified from rat brain block the cell cycle of PC12D cells. J Physiol (Lond) 156:17-23.

Kjellén L, Lindahl U (1991) Proteoglycans: structures and interactions. Annu Rev Biochem 60:443-475.

Laemmli UK (1970) Cleavage of structural proteins during the assembly of the head of bacteriophage T4. Nature 227:680-685.

Lafont F, Rouget M, Triller A, Prochiantz A, Rousselet A (1992) In vitro control of neuronal polarity by glycosaminoglycans. Development 114:17-29.

Lafont F, Prochiantz A, Valenza C, Petitou M, Pascal M, Rouget M, Rousselet A (1994) Defined glycosaminoglycan motifs have opposite effects on neuronal polarity in vitro. Dev Biol 165:453-468.

Landolt RM, Vaughan L, Winterhalter KH, Zimmermann DR (1995) Versican is selectively expressed in embryonic tissues that act as barriers to neural crest cell migration and axon outgrowth. Development 121:2303-2312.

Levine JM (1994) Increased expression of the NG2 chondroitin-sulfate proteoglycan after brain injury. J Neurosci 14:4716-4730.

Litwack ED, Stipp CS, Kumbasar A, Lander AD (1994) Neuronal expression of glypican, a cell-surface glycosylphosphatidylinositolanchored heparan sulfate proteoglycan, in the adult rat nervous system. J Neurosci 14:3713-3724.

Lories V, DeBoeck H, David G, Cassiman J-J, Van Den Berghe H (1987) Heparan sulfate proteoglycans of human fibroblasts. J Biol Chem 262:854-859.

Maeda N, Noda M (1996) 6B4 proteoglycan/phosphacan is a repulsive substratum but promotes morphological differentiation of cortical neurons. Development 122:647-658.

Maurel P, Rauch U, Flad M, Margolis RK, Margolis RU (1994) Phosphacan, a chondroitin sulfate proteoglycan of brain that interacts with neurons and neural cell-adhesion molecules, is an extracellular variant of a receptor-type protein tyrosine phosphatase. Proc Natl Acad Sci USA 91:2512-2516.

McAdams BD, McLoon SC (1995) Expression of chondroitin sulfate and keratin sulfate proteoglycans in the path of growing retinal axons in the developing chick. J Comp Neurol 352:594-606.

Nichol KA, Everett AW, Schulz M, Bennett MR (1994) Retinal ganglion cell survival in vitro maintained by a chondroitin sulfate proteoglycan from the superior colliculus carrying the HNK-1 epitope. J Neurosci Res 37:623-632.

Nichol KA, Schulz MW, Bennett MR (1995) Nitric oxide-mediated death of cultured neonatal retinal ganglion cells: neuroprotective properties of glutamate and chondroitin sulfate proteoglycan. Brain Res 697:1-16.

Oakley RA, Tosney KW (1991) Peanut agglutinin and chondroitin-6sulfate are molecular markers for tissues that act as barriers to axon advance in the avian embryo. Dev Biol 147:187-206.

Oakley RA, Lasky CJ, Erickson CA, Tosney KW (1994) Glycoconjugates mark a transient barrier to neural crest migration in the chicken embryo. Development 120:103-114.

Okamoto M, Mori S, Ichimura M, Endo H (1994) Chondroitin sulfate proteoglycans protect cultured rat's cortical and hippocampal neurons from delayed cell death induced by excitatory amino acids. Neurosci Lett 172:51-54

Oohira A, Matsui F, Katoh-Semba R (1991) Inhibitory effects of brain 
chondroitin sulfate proteoglycans on neurite outgrowth from PC12D cells. J Neurosci 11:822-827.

Perris R, Krotoski D, Lallier T, Domingo C, Sorrell JM, Bronner-Fraser M (1991) Spatial and temporal changes in the distribution of proteoglycans during avian neural crest development. Development 111:583-599.

Pindzola RR, Doller C, Silver J (1993) Putative inhibitory extracellular matrix molecules at the dorsal root entry zone of the spinal cord during development and after root and sciatic nerve lesions. Dev Biol 156:34-48.

Poston MR, Jhaveri S, Schneider GE, Silver J (1988) Damage of a midline boundary and formation of a tissue bridge allows the misguidance of optic axons across the midline in hamsters. Soc Neurosci Abstr 14:595.

Rapraeger A, Yeaman C (1989) A quantitative solid-phase assay for identifying radiolabeled glycosaminoglycans in crude cell extracts. Anal Biochem 179:361-365.

Rapraeger A, Jalkanen M, Endo E, Koda J, Bernfield M (1985) The cell surface proteoglycan from mouse mammary epithelial cells bears chondroitin sulfate and heparan sulfate glycosaminoglycans. J Biol Chem 260:11046-11052.

Rauch U, Geo P, Janetzko A, Flaccua A, Hilgenberg L, Tekotte H, Margolis RK, Margolis RU (1992) Cloning and primary structure of neurocan, a developmentally regulated, aggregating chondroitin sulfate proteoglycan of brain. J Biol Chem 267:19536-19547.

Ring C, Lemmon V, Halfter W (1995) Two chondroitin sulfate proteoglycans differentially expressed in the developing chick visual system. Dev Biol 168:11-27.

Schaffner W, Weissman C (1973) A rapid, sensitive, and specific method for the determination of protein in dilute solution. Anal Biochem 56:502-514.

Schneider GE (1973) Early lesions of superior colliculus: factors affecting the formation of abnormal retinal projections. Brain Behav Evol 8:73-109.

Sheppard AM, Hamilton SK, Pearlman AL (1991) Changes in the distribution of extracellular matrix components accompany early morpho- genetic events of mammalian cortical development. J Neurosci 11:3928-3942.

Snow DM, Letourneau PC (1992) Neurite outgrowth on a step gradient of chondroitin sulfate proteoglycan (CS-PG). J Neurobiol 23:322-336.

Snow DM, Steindler DA, Silver J (1990a) Molecular and cellular characterization of the glial roof plate of the spinal cord and optic tectum: a possible role for a proteoglycan in the development of an axon barrier. Dev Biol 138:359-376.

Snow DM, Lemmon V, Carrino DA, Caplan AI, Silver J (1990b) Sulfated proteoglycans in astroglial barriers inhibit neurite outgrowth in vitro. Exp Neurol 109:111-130.

Snow DM, Watanabe M, Letourneau PC, Silver J (1991) A chondroitin sulfate proteoglycan may influence the direction of retinal ganglion cell outgrowth. Development 113:1473-1485.

So KF, Schneider GE (1978) Abnormal recrossing of retinotectal projections after early lesions in Syrian hamsters: age-related effects. Brain Res 147:277-295.

Sower A, Young MJ, Jhaveri S (1996) Co-cultures of tectal astrocytes and retinal neurons: an in vitro model system for studying axon-glia interaction. Soc Neurosci Abstr 22:33.

Streit A, Nolte C, Rásony T, Schachner M (1993) Interaction of astrochondrin with extracellular matrix components and its involvement in astrocyte process formation and cerebellar granule cell migration. J Cell Biol 120:779-814.

Wu D-Y (1991) Radial glia in the developing superior colliculus: evidence for a midline barrier. PhD thesis, Massachusetts Institute of Technology.

Wu D-Y, Jhaveri S, Schneider GE (1995) Glial environment in the developing superior colliculus of hamsters in relation to the timing of retinal axon ingrowth. J Comp Neurol 358:206-218.

Yamada H, Watanabe K, Shimonaka M, Yamaguchi Y (1994) Molecular cloning of brevican, a novel brain proteoglycan of the aggrecan/versican family. J Biol Chem 269:10119-10126.

Zaremba S, Guimaraes A, Kalb RG, Hockfield S (1989) Characterization of an activity-dependent, neuronal surface proteoglycan identified with monoclonal antibody Cat-301. Neuron 2:1207-1219. 